\title{
DAMPAK TINGKAT PROFITABILITAS DAN NILAI PASAR PADA PERGERAKAN HARGA SAHAM PT. PRASIDHA ANEKA NIAGA TBK
}

\author{
Praja Kussuma \\ Universitas Pendidikan Indonesia \\ praja.kussuma@student.upi.edu \\ Ahim Surachim \\ Universitas Pendidikan Indonesia \\ ahimsurachim@upi.edu \\ Heraeni Tanuatmodjo \\ Universitas Pendidikan Indonesia \\ heraenitanuatmodjo@upi.edu
}

\begin{abstract}
Purpose: This study aimed to obtain an overview of the level of profitability, market value, and stock of price in PT. Prasidha Aneka Niaga Tbk Period 2005-2014. In addition, this study aimed to obtain profitability linkage to the stock price and relation of market value to the stock price on PT. Prasidha Aneka Niaga Tbk Period 2005-2014.

Design / methodology / approaches: This study used a descriptive and verification method with time series design. The statistical analysis used is multiple linear regressions.

Findings: Based on the findings, it could be proved that the regression model be used to see the effect of profitability and market value of the stock price by test $F$. Whereas with $t$ tests showed that the profitability of positive effect on stock prices, while the market value did not have influence to stock of price.

Originality/ Value: This study could provide insight in analyzing the financial performance of the company, especially in analyzing the company's ability to generate profits, how correctly the company's value in the eyes of investors, and how well the company to increase its stock of price.

Keywords: Profitability, Return on Equity, Market Value, Earnings Per Share, Stock of Price
\end{abstract}

\section{PENDAHULUAN}

Tingginya konsumsi masyarakat terhadap makanan dan minuman menyebabkan minat investor terhadap industri food and beverages semakin tinggi. Setiap perusahaan berusaha meningkatkan kinerjanya dengan menunjukkan prestasi yang ditunjukkan dengan peningkatan harga saham perusahaannya. Kinerja perusahaan yang membentuk nilai perusahaan kadangkala terbentuk berdasarkan harga saham (Brealey, Myers, \& Marcus, 2007). Harga saham dapat dikatakan sebagai indikator keberhasilan perusahaan, dimana kekuatan pasar di bursa ditunjukkan dengan adanya transaksi jual beli saham di pasar modal. Terjadinya transaksi tersebut didasarkan atas pengamatan para investor terhadap prestasi perusahaan dalam meningkatkan keuntungannya (Ragab \& Omran, 2006).

Penelitian mengenai harga saham pada industri food and beverages di New York menunjukkan bahwa potensi pertumbuhan harga saham yang diartikan dari peningkatan volume perdagangan dapat menjadi kesempatan bagi investor untuk berinvestasi (Elliott \& Schaub,
2006). Pada tahun 2014 industri makanan dan minuman secara kumulatif berkontribusi terhadap PDB nonmigas sebesar 36,94\% tumbuh sebesar $8,80 \%$ dari tahun sebelumnya..

Industri makanan dan minuman di Indonesia merupakan salah satu subsektor yang ada di industri manufaktur sektor konsumsi yang terdapat di Bursa Efek Indonesia. Bursa Efek Indonesia (BEI) mencatat indeks saham sektor barang konsumsi masih meningkat secara tahunan (year-to-date) sebesar $12,15 \%$ meskipun pada tahun 2013 terjadi kenaikan harga BBM dan fluktuasi nilai tukar rupiah terhadap dolar Amerika Serikat yang berpengaruh terhadap pergerakan harga saham emiten di sektor ini.

Sektor konsumsi terdiri dari lima subsektor yaitu subsektor makanan dan minuman, rokok, farmasi, kosmetik, dan peralatan rumah tangga. Pertumbuhan konsumsi masyarakat terhadap makanan dan minuman yang besar dikarenakan jumlah penduduk Indonesia yang tinggi sangat menarik minat investor untuk berinvestasi pada industri makanan dan minuman. Industri tersebut selalu menunjukkan 


\section{StrategiC}

pertumbuhan yang positif dan menjadi salah satu industri dengan pertumbuhan tertinggi diantara industri non migas lainnya. Selain itu, industri makanan dan minuman olahan juga selalu menjadi sektor dengan pertumbuhan investasi yang signifikan.

Salah satu perusahaan go public di industri makanan dan minuman yang memproduksi produk olahan terbesar di Indonesia adalah PT. Prasidha Aneka Niaga Tbk. Sebesar $60 \%$ dari total investasi makanan dan minuman di Indonesia merupakan investasi pada pengolahan makanan dan $40 \%$ merupakan investasi pada industri minuman. Saat ini PT. Prasidha Aneka Niaga Tbk menjadi salah satu produsen dan eksportir kopi terbesar pada industri makanan dan minuman di Indonesia. Dalam perkembangan industri makanan dan minuman, PT. Prasidha Aneka Niaga Tbk memiliki masalah internal yaitu harga saham yang kecil apabila dibandingkan dengan perusahaan lain di industri makanan dan minuman. Berikut ini merupakan pergerakan harga saham PT. Prasidha Aneka Niaga Tbk Tahun 2011-2014 yang disajikan dalam Gambar 1 berikut.

Gambar 1 Perkembangan Harga Saham PT. Prasidha Aneka Niaga Tbk Periode 2011-2014

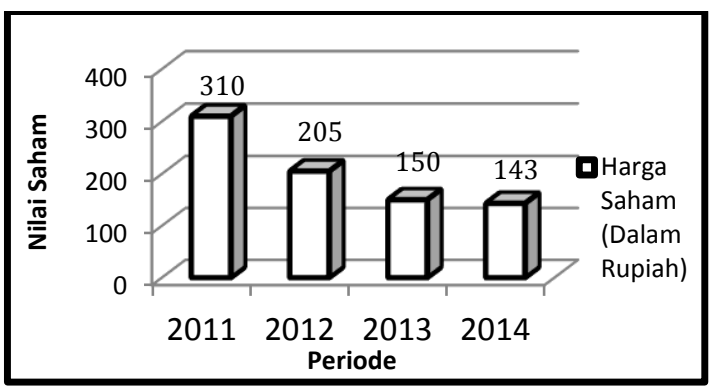

Sumber : www.idx.co.id/Bursa Efek Indonesia (data diolah)

Terlihat bahwa PT. Prasidha Aneka Niaga Tbk mengalami penurunan harga saham secara terus-menerus periode 2011 hingga 2014. Pada tahun 2012 perusahaan mengalami penurunan harga saham sebesar 33,87\%. Kemudian pada tahun 2013 harga saham menurun sebesar 26,83\% dan di tahun 2014 harga saham menurun sebesar $4,67 \%$. Penurunan harga saham secara terus-menerus ini tidak boleh dibiarkan agar perusahaan mendapat kepercayaan dari para investor dan calon investor. Untuk itu, sebuah perusahaan tidak hanya harus meningkatkan harga sahamnya namun juga harus bisa mempertahankannya. Apabila perusahaan selalu mengalami penurunan harga saham maka dapat mengakibatkan turunnya minat para pemegang saham untuk menanamkan modalnya pada perusahaan. Pandangan mengenai prospek perusahaan ini merupakan suatu sinyal untuk investor meningkatkan ataupun menurunkan permintaan terhadap saham, sehingga saat itulah terjadi perubahan terhadap harga saham baik positif maupun negatif.

Salah satu faktor yang mempengaruhi harga saham adalah profitabilitas. Jika kemampuan perusahaan menghasilkan laba meningkat, harga saham akan meningkat sehingga dapat dikatakan profitabilitas mempengaruhi harga saham (Husnan \& Pudjiastuti, 2007). Kemudian faktor lain yang mempengaruhi harga saham selain profitabilitas adalah nilai pasar. Nilai pasar merupakan kinerja yang dapat memberikan informasi seberapa besar masyarakat menghargai perusahaan, sehingga mereka memiliki keinginan untuk membeli saham perusahaan dengan harga yang lebih tinggi dibanding dengan nilai buku saham, sehingga dengan adanya keinginan untuk membeli saham perusahaan dengan harga yang lebih tinggi dapat mempengaruhi peningkatan harga saham itu sendiri maka dapat dikatakan nilai pasar dapat mempengaruhi harga saham (Sutrisno, 2003).

\section{KAJIAN PUSTAKA}

Profitabilitas pada dasarnya mengarah pada kemampuan perusahaan dalam menghasilkan laba, namun rasio profitabilitas bertujuan untuk mengukur efektifitas manajemen yang tercermin pada imbalan atas hasil investasi melalui kegiatan perusahaan atau dengan kata lain mengukur kinerja perusahaan secara keseluruhan dan efisiensi dalam pengelolaan kewajiban dan modal (Sugiono, 2009). Pengertian profitabilitas yaitu kemampuan efektivitas manajemen secara keseluruhan yang ditujukan oleh besar kecilnya tingkat keuntungan yang diperoleh dalam hubungannya dengan penjualan maupun investasi (Fahmi, 2012).

Profitabilitas merupakan suatu pendapatan yang diperoleh oleh perusahaan dari adanya seuatu kegiatan perusahaan yang dijalankan dalam satu periode tertentu. Profitabilitas menjadi indikator untuk menilai baik buruknya kinerja dari sebuah perusahaan dan mencerminkan kemampuan perusahaan dalam menghasilkan laba melalui kegiatan operasional yang dilakukan perusahaan (Herlina, Nugraha, \& Purnamasari, 2016).

Kegunaan profitabilitas tidak hanya berguna bagi investor, profitabilitas yang tinggi juga berguna bagi perusahaan yaitu dapat meningkatkan harga sahamnya. Berdasarkan teori Signalling Hypothesis bahwa ada bukti empiris bahwa jika ada kenaikan laba, sering diikuti dengan kenaikan harga saham. Sebaliknya, penurunan laba pada umumnya menyebabkan 


\section{StrategiC}

harga saham menurun (Mogdiliani \& Miller, 2008).

Terdapat beberapa rasio profitabilitas yang dapat digunakan, diantaranya adalah Gross Profit Margin, Net Profit Margin, Return On Asset, Return On Equity, Rate Return On Loans, dan Net Interest Margin (Kasmir, 2011).

Pengukuran profitabilitas pada umumnya dilihat dari rasio Return On Equity (ROE). ROE merupakan rasio untuk mengukur tingkat pengembalian atas investasi pemegang saham. Tingkat pengembalian yang tinggi akan memungkinkan pendapatan yang diharapkan oleh investor akan naik pula dan hal ini akan berdampak pada peningkatan harga saham (Martono \& Prajitno, 2007).

Selain kemampuan perusahaan dalam menghasilkan keuntungan, prestasi yang dihasilkan oleh sebuah perusahaan dapat meningkatkan nilai pasar perusahaan. Nilai pasar yang ditunjukkan dengan rasio pasar mengindikasikan manajemen mengenai pandangan investor terhadap prestasi sebuah perusahaan dimasa lalu dan prospeknya dimasa mendatang. Nilai pasar merupakan kinerja yang dapat memberikan informasi seberapa besar masyarakat menghargai perusahaan (Sutrisno, 2003).

Rasio nilai pasar dapat diukur dengan menggunakan indikator Earning Per Share, Price Earning Ratio, Book Value Per Share, Dividen Yield, dan Dividen Payout (Fahmi, 2012).

Salah satu rasio nilai pasar yang berpengaruh terhadap harga saham dan sering digunakan oleh investor untuk menganalisis perusahaan adalah Earning Per Share (EPS). Perubahan terhadap laba per lembar saham (EPS) juga mengakibatkan perubahan harga saham (Brigham \& Houston, 2004).

Kesejahteraan sebuah perusahaan dapat tercermin dari harga saham yang terus meningkat. Salah satu indikator dalam mencapai keberhasilan perusahaan adalah dengan meningkatkan harga saham, hal ini dikarenakan harga saham merupakan nilai perusahaan di hadapan investor yang menunjukan baik dan buruknya kinerja perusahaan tersebut (Brealey et al., 2007) (Ragab \& Omran, 2006) (Elliott \& Schaub, 2006). Harga saham adalah harga jual atau beli di pasar efek yang ditentukan oleh kekuatan pasar yang tergantung pada kekuatan permintaan (supply) dan penawaran (request untuk menjual) (Talamati \& Pangemanan, 2015).

Profitabilitas merupakan salah satu faktor yang mempengaruhi harga saham. Pada saat laba (profit) mengalir masuk, harga saham meningkat tajam. Jika kemampuan perusahaan menghasilkan laba meningkat, harga saham akan meningkat sehingga dapat dikatakan profitabilitas mempengaruhi harga saham (Husnan \& Pudjiastuti, 2007). Return On Equity merupakan rasio untuk mengukur tingkat pengembalian atas investasi pemegang saham. Tingkat pengembalian yang tinggi akan memungkinkan pendapatan yang diharapkan oleh investor akan naik pula dan hal ini akan berdampak pada peningkatan harga saham (Martono \& Prajitno, 2007).

Kemudian faktor lain yang mempengaruhi harga saham adalah nilai pasar. Nilai pasar merupakan kinerja yang dapat memberikan informasi seberapa besar masyarakat menghargai perusahaan, sehingga mereka memiliki keinginan untuk membeli saham perusahaan dengan harga yang lebih tinggi dibanding dengan nilai buku saham, sehingga dengan adanya keinginan untuk membeli saham perusahaan dengan harga yang lebih tinggi dapat mempengaruhi peningkatan harga saham itu sendiri maka dapat dikatakan nilai pasar dapat mempengaruhi harga saham (Sutrisno, 2003).

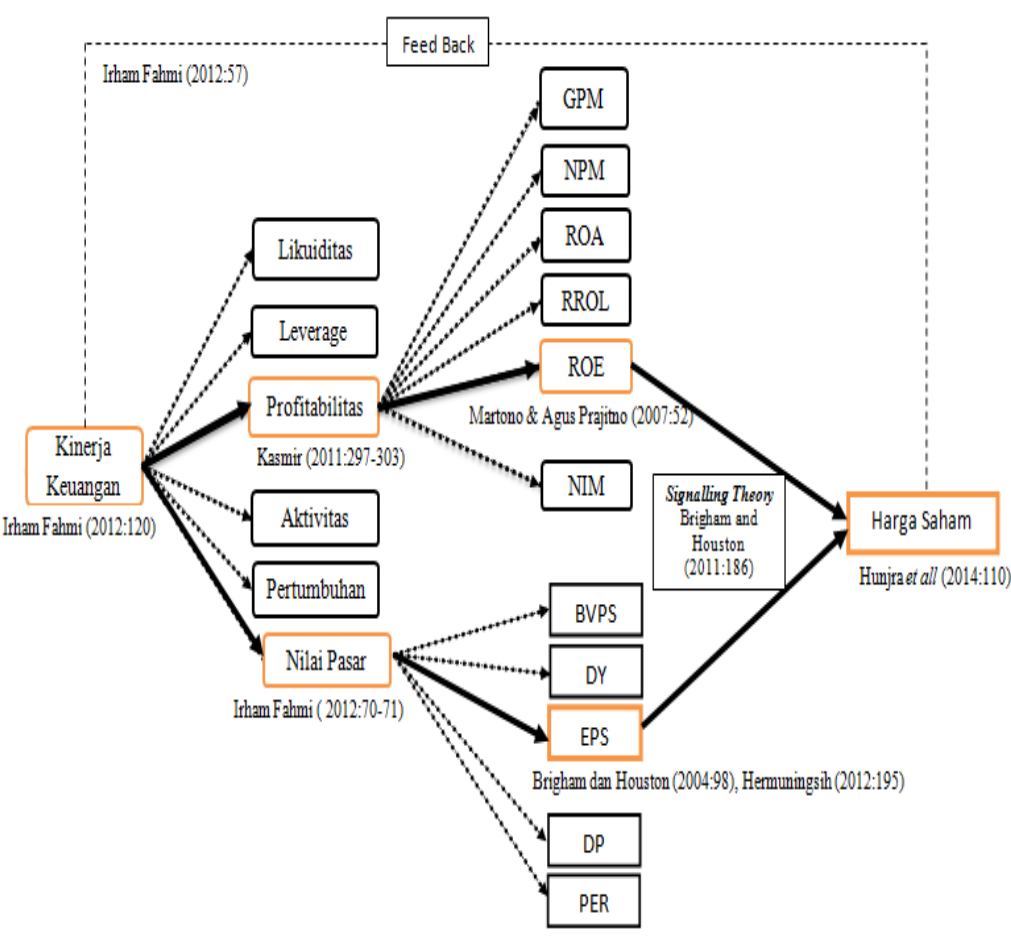

GAVIBAR 2

KERANGKA PEMIKIRAN

PENGARUH PROFITABLITAS DAN NLAI PASAR TERHADAP HARGA SAHAII

Berdasarkan kerangka pemikiran maka disusunlah paradigma penelitian pengaruh profitabilitas dan nilai pasar terhadap harga saham adalah sebagai berikut. 


\section{StrategiC}

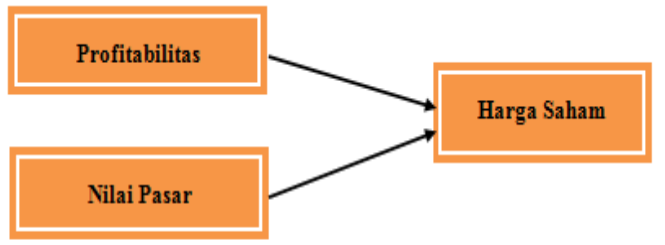

GAMBAR 3

PARADIGMA PENELITIAN PENGARUH PROFITABIITAS DAN NILAI PASAR TERHADAP HARGA SAHAM

Berdasarkan paradigma Gambar 2.2 menunjukkan hipotesis yakni: 1) profitabilitas berpengaruh terhadap harga saham PT. Prasidha Aneka Niaga Tbk, 2) nilai pasar berpengaruh terhadap harga saham PT. Prasidha Aneka Niaga Tbk.

\section{METODE}

Metode penelitian yang digunakan dalam suatu penelitian turut menentukan keberhasilan dalam pencapaian tujuan penelitian. Metode berkenaan dengan cara dan bagaimana memperoleh data yang diperlukan untuk memecahkan masalah yang akan diteliti (Yuniarti \& Karyana, 2010).

Penelitian ini dilakukan dengan menggunakan pendekatan dalam kinerja keuangan untuk mengetahui pengaruh profitabilitas yang diukur menggunakan Return On Equity (ROE) dan nilai pasar yang diukur menggunakan Earning Per Share (EPS) terhadap harga saham. Adapun yang menjadi variabel bebas (independent variabel) dalam penelitian ini adalah profitabilitas dan nilai pasar, sedangkan variabel terikat (dependent variabel) adalah harga saham. Selain itu, penelitian ini dilakukan pada PT. Prasidha Aneka Niaga Tbk periode 20052014. Sampel yang diteliti yaitu laporan keuangan PT. Prasidha Aneka Niaga Tbk periode 20052014.

Metode yang digunakan dalam penelitian ini adalah metode deskriptif verifikatif. Analisis deskriptif digunakan untuk melihat faktor penyebab sedangkan analisis kuantitatif menitik beratkan dalam pengungkapan perilaku variabel penelitian. Untuk analisis verifikatif dilakukan pengujian hipotesis dengan menggunakan uji statistik. Dengan menggunakan kombinasi metode analisis tersebut dapat diperoleh generalisasi yang bersifat komprehensif (Utama \& Aprilliani, 2009).

\section{HASIL PENELITIAN DAN PEMBAHASAN Gambaran Profitabilitas}

Tingkat profitabilitas yang diukur oleh ROE pada PT. Prasidha Aneka Niaga Tbk (Persero) secara keseluruhan rata-rata kurang baik, terlihat pada tahun 2005 hingga 2014 nilai ROE mengalami penurunan maupun peningkatan dan relatif rendah, bahkan nilai ROE tidak mencapai 50 persen. ROE yang paling tinggi pada PT. Prasidha Aneka Niaga Tbk (Persero) tercatat pada tahun 2009 yaitu sebesar 46.7\%. Sedangkan penurunan ROE terjadi pada tahun 2010 hingga 2014 dan nilai terendah terjadi pada tahun 2014 yaitu sebesar $1.39 \%$. Tingkat profitabilitas yang cukup rendah tersebut lebih disebabkan oleh aktivitas penjualan yang kurang efektif, kemudian berdampak pada perolehan laba perusahaan. Penurunan harga komoditas dan penurunan produksi akibat permintaan tertentu akan berdampak pada perolehan tingkat keuntungan perusahaan.

Profitabilitas merupakan ukuran perusahaan dalam menghasilkan keuntungan atas modal dan sumber daya yang dimiliki. Profitability ratio is the company's ability to obtain advantages in managing its assets (Gitman \& Zutter, 2012). Dapat dimaksudkan bahwa rasio profitabilitas merupakan rasio yang mengukur bagaimana perusahaan dapat menghasilkan keuntungan dalam mengelola harta yang dimilikinya.

\section{Gambaran Nilai Pasar}

Tingkat nilai pasar yang diukur menggunakan EPS pada PT. Prasidha Aneka Niaga Tbk (Persero) di Bursa Efek Indonesia pada tahun 2005 hingga 2014 cenderung mengalami penurunan. EPS yang paling tinggi pada PT. Prasidha Aneka Niaga Tbk (Persero) tercatat pada tahun 2005 yaitu sebesar Rp.82. Kemudian pada tahun selanjutnya EPS PT. Prasidha Aneka Niaga Tbk (Persero) mengalami fluktuasi yang artinya peningkatan maupun penurunan dan cenderung menurun. Pada tahun 2013 dan 2014 EPS terus menurun dan nilai EPS terendah pada PT. Prasidha Aneka Niaga Tbk (Persero) tercatat pada tahun 2014 yaitu sebesar Rp.-10. Terjadinya penurunan nilai pasar disebabkan oleh menurunnya laba per lembar saham yang didapatkan oleh investor atas investasi yang diberikannya untuk membiayai operasional perusahaan.

Nilai pasar merupakan keadaan prestasi sebuah perusahaan di mata para pemegang saham pada pasar modal. Market value is the ratio of common and used specifically in the capital markets to portray the state of the situation in the capital market (Gitman \& Zutter, 2012). Dimaksudkan bahwa nilai pasar adalah rasio yang lazim dan khusus dipergunakan di pasar modal untuk menggambarkan situasi keadaan perusahaan di pasar modal.

\section{Gambaran Harga Saham}

Pergerakan harga saham secara keseluruhan pada PT. Prasidha Aneka Niaga Tbk (Persero) tahun 2005 hingga 2014 cenderung mengalami 


\section{StrategiC}

fluktuasi yaitu peningkatan maupun penurunan. Pada tahun 2005 harga saham PT. Prasidha Aneka Niaga Tbk (Persero) yaitu sebesar Rp.80 dan meningkat pada tahun 2006 yaitu sebesar Rp.100. Kemudian pada tahun 2007 harga saham perusahaan menurun dan menjadi harga saham paling kecil yaitu sebesar Rp.51 dan mengalami peningkatan di tahun 2008 yaitu sebesar Rp.100. Pada tahun 2009 harga saham kembali meningkat menjadi Rp.110 dan kemudian menurun di tahun 2010 yaitu sebesar Rp.80. Harga saham paling tinggi pada PT. Prasidha Aneka Niaga Tbk (Persero) tercatat pada tahun 2011 yaitu sebesar Rp.310 dan terus mengalami penurunan pada tahun 2012 hingga 2014. Menurunnya harga saham yang ditunjukkan oleh perusahaan menjadi sinyal negatif bagi investor. Hal tersebut dapat mempengaruhi keputusan berinvestasi pada PT. Prasidha Aneka Niaga Tbk (Persero) karena perusahaan dianggap tidak dapat mengelola manajemen dan tingkat keuntungan yang maksimal.

Harga saham merupakan nilai suatu perusahaan yang dijadikan ukuran keberhasilan perusahaan tersebut oleh investor dan calon investor. Price of assets traded on the stock market should reflect all available information about issuers that should be considered in a efficient in an effecient capital market (Samagaio, 2009). Diartikan bahwa harga saham yang diperdagangkan di pasar modal harus mencerminkan keseluruhan informasi mengenai perusahaan. Hal ini dimaksudkan agar tingkat kepercayaan investor terhadap kinerja dan prestasi perusahaan tersebut tidak menurun.

\section{Keterkaitan Profitabilitas terhadap Harga Saham}

Berdasarkan persamaan regresi linear multipel yang telah diuji pada penelitian ini, nilai konstanta dapat diketahui sebesar -1060,770. Hal tersebut berarti bahwa jika profitabilitas dan nilai pasar tidak mengalami perubahan maka nilai harga saham sebesar -1060,770. Nilai koefisien profitabilitas diketahui sebesar 0,498 menunjukkan bahwa setiap peningkatan profitabilitas sebesar $1.00 \%$ maka akan menyebabkan peningkatan harga saham sebesar 0,498 kali.

Untuk memperoleh hasil mengenai keterkaitan profitabilitas melalui ROE terhadap harga saham dilakukan pengujian dan penelitian pada PT. Prasidha Aneka Niaga Tbk (Persero) tahun 2005 hingga 2014. Adapun dalam penelitian ini melalui uji $\mathrm{t}$ diketahui nilai $\mathrm{t}_{\text {tabel }}$ yaitu 2.306 dan $t_{\text {hitung }}$ yaitu 3.917. Dengan demikian maka $t_{\text {hitung }}>t_{\text {tabel }}$ atau $3.917>2.306$. Kemudian nilai signifikansi dari $t_{\text {hitung }}$ yaitu 0.006 yang berarti bahwa nilai tersebut lebih kecil dari taraf nyata yaitu $5 \%$ atau $0.006<0.05$. Dengan demikian $\mathrm{H}_{0}$ ditolak yang artinya profitabilitas berpengaruh terhadap harga saham.

Kemampuan perusahaan dalam menghasilkan laba (profit) dapat mempengaruhi harga saham perusahaan tersebut. Menurut teori "Signalling Hypothesis" bahwa ada bukti empiris jika ada kenaikan laba, sering diikuti dengan kenaikan harga saham. Sebaliknya, penurunan laba pada umumnya menyebabkan harga saham menurun (Mogdiliani \& Miller, 2008).

\section{Keterkaitan Nilai Pasar terhadap Harga Saham}

Berdasarkan persamaan regresi linear multipel yang telah diuji pada penelitian ini, nilai konstanta dapat diketahui sebesar -1060,770. Hal tersebut berarti bahwa jika profitabilitas dan nilai pasar tidak mengalami perubahan maka nilai harga saham sebesar $-1060,770$. Nilai koefisien nilai pasar diketahui sebesar -1,122 menunjukkan bahwa setiap peningkatan nilai pasar sebesar 1.00 rupiah maka akan menyebabkan penurunan harga saham sebesar -1,122 kali.

Untuk memperoleh hasil mengenai keterkaitan nilai pasar melalui EPS terhadap harga saham dilakukan pengujian dan penelitian pada PT. Prasidha Aneka Niaga Tbk (Persero) tahun 2005 hingga 2014. Adapun dalam penelitian ini melalui uji $\mathrm{t}$ diketahui nilai $\mathrm{t}_{\text {tabel }}$ yaitu 2.306 dan $t_{\text {hitung }}$ yaitu 1.763. Dengan demikian maka $t_{\text {hitung }}<t_{\text {tabel }}$ atau $1.763<2.306$. Kemudian nilai signifikansi dari $t_{\text {hitung yaitu } 0.121}$ yang berarti bahwa nilai tersebut lebih besar dari taraf nyata yaitu 5\% atau 0.121>0.05. Dengan demikian $\mathrm{H}_{0}$ diterima yang artinya nilai pasar tidak berpengaruh terhadap harga saham. Nilai $t_{\text {hitung }}$ negatif yang artinya menunjukkan bahwa nilai pasar memiliki hubungan tidak searah dengan harga saham.

Nilai pasar sebuah perusahaan diciptakan dari apresiasi investor terhadap prestasi perusahaan dalam mengelola keuangan dan manajemennya. Ketika investor mengapresiasi perusahaan yang dapat memberikan imbalan yang memuaskan atas investasinya maka nilai perusahaan yang ditunjukkan oleh harga saham akan meningkat, begitupun sebaliknya. Nilai pasar merupakan kinerja yang dapat memberikan informasi seberapa besar masyarakat menghargai perusahaan, sehingga mereka memiliki keinginan untuk membeli saham perusahaan dengan harga yang lebih tinggi dibanding dengan nilai buku saham, sehingga dengan adanya keinginan untuk membeli saham perusahaan dengan harga yang lebih tinggi dapat mempengaruhi peningkatan harga saham itu sendiri maka dapat dikatakan nilai pasar dapat mempengaruhi harga saham (Sutrisno, 2003). 


\section{StrategiC}

\section{KESIMPULAN DAN REKOMENDASI}

Gambaran profitabilitas pada PT. Prasidha Aneka Niaga Tbk (Persero) tahun 2005-2014 yang diukur dengan menggunakan indikator Return On Equity (ROE) menunjukkan bahwa nilai ROE PT. Prasidha Aneka Niaga Tbk (Persero) tahun 2005-2014 mengalami fluktuasi yaitu peningkatan dan penurunan ROE dan cenderung menurun. Kemudian gambaran nilai pasar pada PT. Prasidha Aneka Niaga Tbk (Persero) tahun 2005-2014 yang diukur dengan menggunakan indikator Earning Per Share (EPS) menunjukkan bahwa nilai EPS PT. Prasidha Aneka Niaga Tbk (Persero) tahun 2005-2014 mengalami fluktuasi yaitu peningkatan dan penurunan ROE dan cenderung menurun. Sementara gambaran dari harga saham pada PT. Prasidha Aneka Niaga Tbk (Persero) tahun 20052014 mengalami fluktuasi yaitu peningkatan dan penurunan ROE dan cenderung menurun selama empat tahun terakhir. Hal ini karena kemampuan perusahaan dalam menghasilkan laba (profit) yang juga mengalami penurunan sehingga harga saham perusahaan menurun.

Berdasarkan hasil penelitian, terdapat pengaruh positif antara profitabilitas terhadap harga saham pada PT. Prasidha Aneka Niaga Tbk (Persero). Peningkatan dan penurunan profitabilitas akan mempengaruhi pergerakan harga saham perusahaan. Kemudian berdasarkan hasil penelitian, tidak terdapat pengaruh antara nilai pasar terhadap harga saham pada PT. Prasidha Aneka Niaga Tbk (Persero). Peningkatan dan penurunan nilai pasar tidak mempengaruhi pergerakan harga saham perusahaan.

Rekomendasi untuk PT. Prasidha Aneka Niaga Tbk (Persero) terutama dalam kinerja keuangan khususnya profitabilitas yang diukur oleh ROE dapat lebih ditingkatkan dengan meningkatkan penjualan. Hal ini diharuskan karena perusahaan membutuhkan dana yang lebih besar untuk membiayai operasional dan dengan meningkatkan laba yang lebih tinggi dapat menarik modal dari investor sehingga keuntungan (profitabilitas) yang didapatkan perusahaan pun akan meningkat. Dengan tertariknya investor maka nilai perusahaan yang ditunjukkan oleh harga saham PT. Prasidha Aneka Niaga Tbk (Persero) pun akan meningkat.

Kemudian rekomendasi bagi PT. Prasidha Aneka Niaga Tbk (Persero) terutama dalam nilai pasar yang diukur oleh EPS dapat lebih ditingkatkan dengan memberikan imbalan yang optimal bagi investor yang telah dan akan berinvestasi. Meningkatnya EPS dapat memberikan nilai positif bagi investor mengenai kemampuan perusahaan dalam memberikan keuntungan yang didapatkan investor yang akan menginvestasikan dananya pada perusahaan.

\section{DAFTAR PUSTAKA}

Brealey, R. A., Myers, S. C., \& Marcus, A. J. (2007). Dasar-Dasar Manajemen Keuangan Perusahaan. Terjemahan Bob Sabran, 2008 (Edisi 5). Jakarta: Erlangga.

Brigham, E. F., \& Houston, J. F. (2004). Fundamentals of Financial Management. United States of America: Horcourt College.

Elliott, R. S., \& Schaub, M. (2006). On The New York Stock Exchange : A Look At Investment Opportunities. International Business \& Economics Research Journal, 5(3), 7-14.

Fahmi, I. (2012). Analisis Laporan Keuangan. Bandung: Alfabeta.

Gitman, L. J., \& Zutter, C. J. (2012). Principles Of Managerial Finance. (13th ed.). Edinburgh: Pearson.

Herlina, Nugraha, \& Purnamasari, I. (2016). Pengaruh Risiko Kredit Terhadap Profitabilitas (Studi Kasus Pada Bank Umum Swasta Nasional Devisa Tahun 2010-2014). Journal of Business Management and Enterpreneurship Education, 1(1), 31-36.

Husnan, S., \& Pudjiastuti, E. (2007). DasarDasar Manajemen Keuangan. Yogyakarta: AMP YKPN.

Kasmir. (2011). Dasar-Dasar Perbankan. Jakarta: PT. Raja Grafindo Persada.

Martono, \& Prajitno, A. (2007). Manajemen Keuangan. Yogyakarta: Ekonisia.

Mogdiliani, \& Miller. (2008). The Cost of Capital, Corporation Finance and The Theory of Investment. The American Economic Review, 13(3), 261-297.

Ragab, A. A., \& Omran, M. M. (2006). Accounting information, value relevance, and investors' behavior in the Egyptian equity market. Review of Accounting and Finance, 5(3), 279-297. http://doi.org/10.1108/14757700610686444

Samagaio, A. et al. (2009). Sporting, Financial and Stock Market Performance In English Football: An Empirical Analysis of Structural Relationships. Journal Department of Management, ISEG/School of Economics and Management, Techincal University of Lisbon, Portugal.

Sugiono, A. (2009). Manajemen Keuangan Untuk Praktisi Keuangan. Jakarta: PT Gramedia Widiasarana Indonesia.

Sutrisno. (2003). Manajemen Keuangan Teori, Konsep, dan Aplikasi. Yogyakarta: Ekonisia. 
Talamati, M. ., \& Pangemanan, S. (2015). The Effect Of Earnings Per Share (EPS) \& Return On Equity (ROE) On Stock Price Of Banking Company Listed In Indonesia Stock Exchange (Idx) 2010-2014. Jurnal EMBA., 3(2), 1086-1094.

Utama, D. H., \& Aprilliani, R. (2009). Pengaruh Program Consumer Promotion Nada Sambung Pribadi (NSP) 1212 Telkomsel Terhadap Respon Konsumen Dalam Penggunaannya (Survei pada Mahasiswa FPIPS UPI Bandung). Jurnal Pendidikan Manajemen Bisnis, 8(15), 17-34.

Yuniarti, R. D., \& Karyana, D. (2010). Pengaruh Pendapatan Usaha Terhadap Kemampuan Pengembalian Kredit (Studi Kasus pada NPL (Non Performing Loan) SPP-UPK Samarang Garut Periode Januari 2007- Juni 2009). Jurnal Pendidikan Manajemen Bisnis, 9(18), 49-57. 